\title{
Using A Constructivist Approach to Improve Students' Comprehension in Reading Descriptive Text at The Seventh Grade of SMP Negeri 24 Pekanbaru
}

\author{
Herdi Herdi and Reka Santika \\ Universitas Lancang Kuning, Pekanbaru, Indonesia \\ herdi@unilak.ac.id
}

\begin{abstract}
ARTICLE HISTORY
Received : 12 August 2020

Revised : 27 August 2020

Accepted : 27 September 2020
\end{abstract}

\section{KEYWORDS}

Constructivist Approach

Reading Comprehension

Descriptive Text

\begin{abstract}
The problem of this research is the students' low comprehension in reading descriptive text in term of generic structure, purpose, language features and vocabulary. This research aimed to enhance student understanding by using a constructivist approach in reading descriptive text. The design of this research was a classroom action research (CAR). The samples of this research were 40 junior high school students. Based on the result of the test, it was found that students' average score was 77 . The resulting score improved from the based score that was 69.5. Furthermore from the result of observation, field note and interview, it was found the factors influencing the improvement of students' comprehension in reading descriptive text by using a constructivist approach, they were teacher's strategy and teacher's media. Finally, the researcher concludes that this constructivist approach can improve the students' reading comprehension
\end{abstract}

\section{Introduction}

Reading is one of the necessary language skills that should be mastered by the student. It is because reading is useful to get information, knowledge and values. Reading is an idea and knowledge method from a written source. Many think that reading is the best way to obtain information from a document. Reading is a method of gathering ideas and information from a written source. Most think reading is the most effective way of obtaining information from the text (Marpaung et al., 2020). By reading, people can get the information in a text and make meaning from it. To classroom setting in the Indonesian context, reading is taught as short functional texts and in term of various text types.

According to Curriculum 2013, teaching reading in junior high school aims to develop the students' ability to comprehend descriptive text. Descriptive text is a text describing a particular person, place or thing. The goal of the descriptive text is to explain, represent or disclose a person or object as this research is focused on it.

The researcher chose the constructivist approach to solve the problem. Constructivism approach is a learning approach that is expected to make the learning atmosphere more active to develop and build knowledge to improve student learning outcomes. Hanifah \& Suhana (2009) stated that the constructivism approach in learning is one of the more student-centred approaches as the centre in the learning process. This approach is presented to be more stimulating and provide opportunities for students to learn innovative thinking and develop their potential optimally.

\subsection{Theory of Reading}

Reading is one of the critical factors of the four skills in English. Students require second language English. Bell (2005), reading is a dynamic process and which the reader work actively to construct meaning from the material.

Brown (2004) adds that reading is a method of sense negotiation. In this cycle, readers bring their early learning to the rest of the reading process so that they eventually understand the meaning of the text. Snow (2002) also notes that reading in a vacuum is not feasible. It's done to one point. The reading task includes one or more porpuses, the object of the text at hand and the implications of carrying out the activity. It means that reading requires porpuses in a text or a paragraph to allow readers to understand the subject or principal concept.

According to Prasetyo \& Abbas (2017), reading is a process to get meaning from words, phrases, clauses, sentences and text. Reading is one of the crucial skill that should be mastered by the students in learning English after listening, speaking, and writing. It connects the writer or author to the reader. It was building communication between the reader and writer in understanding a printed material or text. Through reading, readers can get much knowledge that can be useful in getting information.

Based on the definition of some experts above, it can be concluded that reading is not only the relationship between the text and reader's background knowledge but also the relationship between author and the text and the reader can get intended meaning from the text. Reading also provides a situation of the students to analyze what the writer purpose in the text. 


\subsection{Theory of Reading Comprehension}

Reading is the most important activity in the language class. Reading also can make understand and comprehend some point from the text. Reading comprehension refers to the ability to understand information from the text. There are many definitions of reading comprehension that accept from some writers.

Klingner (2007) states that Reading comprehension is the process of constructing meaning by coordinating several complex processes that include word reading, word, and word knowledge and fluency. It means the process to comprehend the text we must know the word in the text. So, we get the meaning of the text. Also

Kemil (2003) reading comprehension is about relating prior knowledge to new knowledge contained in written text. Prior knowledge, in turn, depend on lived experience. The topic that is familiar and openly discussed in one culture may be unacceptable in another. Children growing up in rural communities was have different experiences from those from urbanizes, developing countries. Because having more prior knowledge of generally facilities comprehension, having more cultural knowledge has the same effect. The statement above explains reading comprehension is related to prior knowledge of students. The students were known to new knowledge contained in written text. Prior knowledge helps them to comprehend the text.

Grabe and Stoller (2002) state that "general reading comprehension is the most basic purpose of reading, underlying and supporting most other purposes for reading.

Furthermore, snow (2002), reading comprehension is a complex activity that involves interaction between the readers and the text. It means that the reader reading comprehension is a process to know whether the reader understands or not about a text that the reader read.

From the above description, reading comprehension can be inferred as the ability to find writer knowledge. The essence of reading understanding is the comprehension of all the writer's knowledge. It also refers to the ability, in a text, to connect the world and to understand the ideas and connections between ideas conveyed in a text.

\subsection{Descriptive Text}

Descriptive text provides vivid details of how someone appears. A text describes how a person or thing is. The aim is too descriptive and exposes a specific person, place or thing. The text just reveals the reality because the characteristics of the item are descriptive, and most clauses use adjectives. The descriptive text often usually shows a full-blown partnership.

Ewen (2005) defines descriptive text as an entity, person, or scene. This may be true or subjective classification. You provide factual information about what you have experienced without disclosing your feelings in an objective description. You select and express details in a subjective description to show your attitude towards what you describe.

In addition, Kane (2000) states that description deals with perceptions, most commonly visual perceptions. Its central problem is to arrange what we see into a significant pattern. The description helps the reader, though his/her imagination, to visualize a scene or a person, or to understand a sensation or an emotion.

In line with the above paragraph, descriptive text can be concluded that a text which the characteristics of something. Every type of text has specific features. First, social function is the purpose of why the writer writes the text. In this step, the students can make a paragraph in generally. Second, Generics structure is the organizational structure of the text. In generic structure, that consists of identification and description.

\subsubsection{The social function of Description Text}

Zahrowi (2009) descriptive text is usually also used to help the writer develop an aspect of their work, places, objects etc. To complete our intention. The characteristics based on descriptive write or text, below; as a feature, the description is a style of writing which can be useful for other variety of purposes as:

1) To engage a reader's attention

2) To create characters

3) To set a mood or create an atmosphere

4) To boing writing to life

\subsubsection{Generic structure of the descriptive text}

The generic structure of descriptive text consists of identification and description they are:

1) Identification is a part to introduces or identifies the character.

2) The description is a part to describes the character.

\subsubsection{Language features of description text}

The description text has dominant language features as follows:
1) Using noun
2) Using simple present tense
3) Using adjective
4) Using figurative language.

\subsection{Reading Assessment}

Assessing reading comprehension is about giving feedback and assistance of learners for effective reading instruction. Assessing reading comprehension aims to identify how well students in learning reading to help them improve and measure how much progress has been made. In this research, the goal of reading comprehension is the comprehending of descriptive text. There is some component of description text 


\subsubsection{The social function of descriptive text}

It is purpose is to describe a particular person, place, people, or thing

\subsubsection{Generic structures of descriptive text consist of :}

1) Identification

2) Description

\subsubsection{Language features of description text}

The descriptive text contains some component or language feature, they are:

1) Verbs. The tense is simple present tense and verb

2) Tense (using the simple present tense)

3) Using noun

4) Using adjective

In conclusion, to promote an understanding of the descriptive text for students, the teacher can develop the students' mind by designing comprehension question which involved in some indicators: find the social function of descriptive text, find the generic structure of the descriptive text, and find the language feature of descriptive text, like noun and adjective. All indicators can be used as a multiple-choice in testing reading comprehension and the process improvement in reading comprehension of descriptive text by using a constructivist approach

\subsection{Constructivist Approach}

\subsubsection{The definition of a Constructivist Approach}

Constructivist approach is a learning theory found in psychology which explains how people might acquire knowledge and learn. The theory suggests the people construct their knowledge and meaning for their experiences. Constructivist is affected by the context in which an idea taught as well by students' beliefs and attitude.

According to Discroll (2000), constructivist approach is a philosophy which enhances students' logical and conceptual growth. The underlying concept within the constructivist learning theory is the role which experiences or connections with adjoining atmosphere-play in students education. Constructivist learning argues that people produce knowledge and form meaning based upon their experiences.

Two of the concepts learning theory which creates the construction of an individual's new knowledge are accommodation and assimilations. Assimilation is an individual to incorporate new experiences into the old experiences. This causes the individual to develop new outlooks, re-think what was once misunderstanding, and evaluate what is important. Accommodation is reframing the world and new experiences into the mental capacity already present.

\subsubsection{The Procedure of the Constructivist Approach}

The teaching-learning process of the course in which action research will conduct as follows Suprijono (2009):

1) Orientation is a phase to allow students to pay attention and develop the motivation for the topic of learning material.

2) Elicitation is a stage to help students to explore their ideas by allowing students to discuss or describe their basic knowledge or ideas through posters, writings presented to all students.

3) Reconstruction of ideas, in this stage, students clarify the idea by contrasting their ideas with the ideas of others or friends through discussion. Confronted with other ideas, a person can be aroused to reconstruct his or her speech. Otherwise, it fits. Instead, be sure if the gag matches.

4) Application of ideas, in this step ideas or knowledge that has been formed, students need to be applied to the various situations encountered. This will make the student's knowledge more complete, even more detailed.

5) Review, in this phase, allows students to apply their knowledge to the situation faced daily, revise by adding a description or by changing it more fully. If the results of the review then compared with the fundamental knowledge that has been owned, it will bring back the ideas (elicitation) in students.

Based on the opinions, the Researcher uses the learning steps of the constructivism approach because it is more detailed and systematic in the process. Steps are used as follows. (1) Orientation, allowing students to observe and develop the motivation of idea to the topic of learning material. (2) Elicitation, this stage of the teacher helps the student to develop his ideas. (3) Reconstruction of ideas, students clarify ideas by contrasting their ideas with the ideas of others or friends through discussion. (4) Application of ideas, students, communicate the results of the investigation and findings, this stage the teacher becomes a facilitator in accommodating the opinions of students, and (5) review or revise the student's ideas by adding a description or by changing them to be more complete.

\section{Method}

The researcher was classroom action research. This study was a kind of action research. Action research was done to acquire information to solve the problems that are faced in a certain condition or situation. According to Creswell (2005), action research design are systematic procedures use by teacher or researcher together quantitative and qualitative data to address improvement in their educational setting their teaching and the learning of their students. Action research is one of the methods for the 
design of procedures uses by researcher or teachers. The research aims to improve the educational setting in the teaching and learning process of students.

In the research, the researcher applied the constructivist approach to improving students' comprehension in reading descriptive text at the seventh grade of SMP Negeri 24 Pekanbaru. To observe the activities of the researcher and the students during the teaching and learning process, the researcher needed teacher-collaborator since classroom action researcher is a collaborative action. The researcher chose the English teacher at the seventh grade of SMP Negeri 24 Pekanbaru as teacher collaborator. The researcher expected that by having the collaboration with the teacher - collaborator, the activities of the researcher and the students during and learning process can be observed well..

\section{Results}

By conducting the research, the researcher would like to explain what the researcher had found by conducting this research. This research was conducted in SMP Negeri 24 Pekanbaru at the seventh-grade class VII.3. They have consisted of 40 students with 20 males and 20 females. This chapter presents a description of data analysis. There is two research question that should be answered in this chapter. There where "To what extent can constructivist approach improve students' low comprehension in reading descriptive text at the seventh grade of SMP Negeri 24 Pekanbaru? And "What factors influence the changing of students' comprehension in reading descriptive text by using a constructivist approach at the seventh grade of SMP Negeri 24 Pekanbaru?". Base on the questions would be answered the data obtained from the test, observation checklist, field note, and interview.

After analyzing both quantitative and qualitative data, the researcher examined whether the constructivist approach could improve the students' reading comprehension. The result below:

Table 1. Students' Reading Comprehension of Descriptive Text from Based Score to Cycle 1

\begin{tabular}{cc}
\hline The Name of Score & The Average Score \\
\hline Based Score & 69,5 \\
\hline Cycle 1 & 77 \\
\hline
\end{tabular}

Figure 1. Students' Reading Comprehension of Descriptive Text from Based Score to Cycle 1

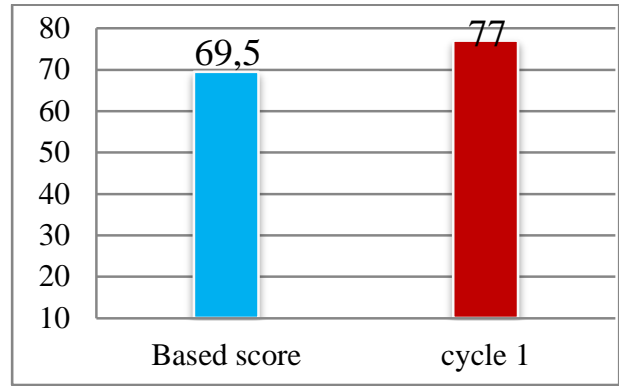

The students' improvement was found in their reading comprehension of descriptive text. The average score in based score was 69,5, and cycle I was 77 . It could be concluded that this strategy could improve and passed the minimum score of the curriculum (KKM). From the students' reading comprehension in descriptive text test results, it can be concluded that students reading comprehension can be improved by using the constructivist approach.

\section{Conclusion}

After conducting this classroom action research in improving reading comprehension of the seventh-grade students at SMP Negeri 24 Pekanbaru by applying the constructivist approach, the researcher concludes this research into some conclusion as follow:

1) Teaching reading by using the constructivist approach can better improve the students' comprehension in reading descriptive text at the seventh grade of SMP Negeri 24 Pekanbaru. It can be seen from the achievement of students from this cycle.

2) Teaching reading descriptive text by using the constructivist approach has some factors that can be increasing students' reading comprehension:

\section{Teacher Media}

The teacher can guide the students to read some interesting text. In the learning process, the teacher uses the picture on the text. That made the students fell more interesting to read.

\section{Teachers Strategy}

Constructivist approach helps the students to understand the content of the text.

\section{References}

Alesandrini, K., \& Larson, L. (2002). Teachers bridge to constructivism. The clearing house, 75(3), 118-121.

Amalia, F. The Impact Of Constructivist Approach And Learning Motivation Towards Problem Solving Competency And Mastery Concept Of Basic Programming Competency In Smk 6 Malang.

Anderson, M., \& Anderson, K. (2003). Text Types in English 1-2 Australia: Macmillan Education Australia PTY. 
Bell, T. (1998). Extensive reading: Why? and how. The Internet TESL Journal, 4(12), 1-6.

Brooks, J. G., \& Brooks, M. G. (1993). In search of understanding: the case for constructivist classrooms. Alexandria, VA: Association for Supervision and Curriculum Development. Bybee, RW (2003). Why the seven E's. Educational foundations: An anthology of critical readings, 184-194.

Brown, H. D. (2016). Teaching by principles.

Carla, (2006). Factor That Affect Reading Comprehension. Retrieved on 14 August 2015 from http://www.Slideshare.Net/jeanecarlaong/CognitiveFactor-That-Affect Reading-Comprehension

Clark, V. L. P., \& Creswell, J. W. (2005). Student study guide to accompany Creswell's educational research: planning, conducting, and evaluating quantitative and qualitative research. Merrill.

Douglas, B. H. (2004). Language assessment principles and classroom practice. NY: Pearson Education.

Driscoll, M. P. (1994). Psychology of learning for instruction. Allyn \& Bacon.

Grabe, W., \& Stoller, F. L. (2019). Teaching and researching reading. Routledge.

Hanafiah, N., \& Suhana, C. (2009). Konsep Strategi Pembelajaran, Bandung: PT. Refika Aditama.

Harkness, L. M. (2016). The effect of a constructivist-based approach on fifth grade reading achievement.

Herdi, H. (2014). The Abilities in Applying Verb Tenses in Writing Sentence Using Mixed Model. ELT-lectura, 1(1).

Honebein, P. C. (1996). Seven goals for the design of constructivist learning environments. Constructivist learning environments: Case studies in instructional design, 11-24.

Kahayanto, E. (2005). A Comparative Study on Students' Achievement in Reading of the Education Study Program of Palangka Raya University who Entered Through PSB and SPMB in Academic Year 2003/2004. Unpublished Thesis. Palangka Raya: The Faculty of Teacher Training and Education University of Palangka Raya, 13.

Klingner, J. K., Vaughn, S., \& Boardman, A. (2015). Teaching reading comprehension to students with learning difficulties, 2/E. Guilford Publications.

Marlowe, B. A., \& Page, M. L. (2005). Creating and sustaining the constructivist classroom. Corwin Press.

Marpaung, A. P., Yanti, I., \& Marzuki, Y. (2019). Developing Students' Reading Comprehension Using STAD Strategy: A Classroom Action
Research at SMA Negeri 7 Pekanbaru. REiLA : Journal of Research and Innovation in Language, $1(1)$, 10-16. https://doi.org/10.31849/reila.v1i1.2775

Mvududu, N., \& Thiel-Burgess, J. (2012). Constructivism in practice: The case for English language learners. International Journal of Education, 4(3), 108.

Pandian, A., Ling, C. L. C., \& Lin, D. T. A. (Eds.). (2014). New Literacies: Reconstructing Language and Education. Cambridge Scholars Publishing.

Patel, M. F., \& Jain, P. M. (2008). English language teaching. Sunrise Publishers and Distributors.

Perwitasari, C. A. (2018). The Implementation Of Jigsaw Technique And Student Teams Achievement Division (Stad) In Teaching Reading Recount Text At Second Grade Of Smpn 1 Abung Surakarta, North Lampung.

Presetyo, W., \& Abbas, M. F. F. (2017). The Use Of Questioning The Author (Qta) Strategy In Improving Students'ability In Reading Descriptive Text At The Seventh Grade Students Of Smp Islam Plus Jannatul Firdaus Pekanbaru. ELT-Lectura, 4(2).

Snow, C. (2002). Reading for understanding: Toward an R\&D program in reading comprehension. Rand Corporation.

Suprijono, A. (2009). Cooperative learning: teori \& aplikasi PAIKEM. Pustaka Pelajar.

Uzuntiryaki, E. (2003). Effectiveness of constructivist approach on students' understanding of chemical bonding concepts (Doctoral dissertation, METU).

Yunita, A. (2014). Using Constructivist Approach to Enhance Students' Comprehension in Reading Procedure Text (Doctoral dissertation, Indonesia University Of Education). 